THE WELFARE STATE IN BRITAIN SINCE 1945 


\section{The Welfare State in Britain since 1945}

Rodney Lowe

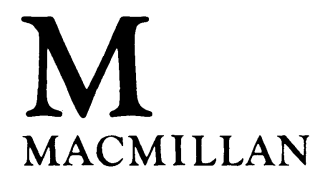




\section{(C) Rodney Lowe 1993}

All rights reserved. No reproduction, copy or transmission of this publication may be made without written permission.

No paragraph of this publication may be reproduced, copied or transmitted save with written permission or in accordance with the provisions of the Copyright, Designs and Patents Act 1988, or under the terms of any licence permitting limited copying issued by the Copyright Licensing Agency, 90 Tottenham Court Road, London W1P 9HE.

Any person who does any unauthorised act in relation to this publication may be liable to criminal prosecution and civil claims for damages.

First published 1993 by

THE MACMILLAN PRESS LTD

Houndmills, Basingstoke, Hampshire RG21 2XS

and London

Companies and representatives

throughout the world

ISBN 978-0-333-44256-2 ISBN 978-1-349-22549-1 (eBook)

DOI 10.1007/978-1-349-22549-1

A catalogue record for this book is available from the British Library.

Phototypeset by Intype, London 


\section{Contents}

List of Figures and Tables

Acknowledgements

viii

1 Introduction 1

\section{PART I THEORETICAL PERSPECTIVES}

2 The Nature of the Welfare State 9

2.1 The definition of the welfare state 9

2.2 The three pragmatic approaches to welfare in

2.2.1 Reluctant collectivism 16

2.2.2 Democratic socialism 18

2.2.3 The New Right 23

2.2.4 The political divide 26

2.3 General theories of social welfare 27

2.3.1 Pluralism, elitism and corporatism 27

2.3.2 Marxism 29

2.3.3 Feminism 33

2.4 Conclusion $\quad 35$

2.5 Further reading 38

3 The Nature of Policymaking 39

3.1 The political science perspective 39

3.1.1 The three faces of power 39

3.1.2 Bureaucracy and the formulation of policy 41

3.1.3 The implementation of policy 46

3.1.4 Incrementalism 48

3.2 The economic perspective 49

3.2.1 The economics of state intervention 53

3.2.2 The economics of individual welfare policies $\quad 58$

3.2.3 Economic rationality 60

3.3 Further reading 61 


\section{PART II THE CLASSIC WELFARE STATE, 1945-75}

4 The Historical Context $\quad 65$

4.1 The economic context 66

4.2 The demographic context $\quad 70$

4.3 The political context $\quad 75$

4.4 The administrative context 85

4.5 The cultural context 91

4.6 Conclusion 97

4.7 Further reading 99

5 Employment Policy 99

5.1 The commitment to full employment 100

5.2 The management of the economy 104

5.3 Direct industrial intervention 113

5.4 Conclusion 119

5.5 Further reading 120

6 Social Security 122

6.1 The Beveridge Report and its critics 125

6.2 The 'rediscovery' of poverty 135

6.3 The abandonment of Beveridge 141

6.4 The targeting of need 150

6.5 Conclusion 159

6.6 Further reading 161

7 Health Care 163

7.1 The establishment of the National Health Service, 1943-51 166

7.2 Consolidation and reconstruction, 1951-74 179

7.3 The delivery of health care 186

7.4 Conclusion 190

7.5 Further reading 192

8 Education 193

8.1 The 1944 Education Act and its critics 196

8.2 Education and equality 203

8.3 The collapse of tripartism 213

8.4 The maintenance of educational standards 218

8.5 Technical education 228

8.6 Conclusion 232

8.7 Further reading 233 
9 Housing 235

9.1 Planning 238

9.2 Housing construction $\quad 244$

9.3 Housing costs $\quad 254$

9.4 Conclusion 259

$\begin{array}{ll}9.5 \text { Further reading } & 259\end{array}$

10 The Personal Social Services 261

10.1 The statutory services 263

10.2 Voluntary provision $\quad 271$

10.3 Conclusion $\quad 277$

10.4 Further reading 278

11 The Achievement 280

11.1 Equality $\quad 282$

11.2 Efficiency 293

11.3 Conclusion 296

11.4 Further reading 297

PART III THE WELFARE STATE SINCE 1976

12 The Welfare State under Threat 301

12.1 The political and economic context 304

12.2 Social security and the personal social services 313

12.3 Health care, education and housing 319

12.4 Conclusion 328

12.5 Further reading 329

Appendix: The Cost of Welfare Policy 331

1.1 Estimates of the national product 331

1.2 Definitions of public expenditure 332

1.3 Trends in welfare expenditure 333

1.4 Employment in the public and welfare sectors 334

1.5 Further reading 335

Notes and References $\quad 342$

$\begin{array}{ll}\text { Index } & 378\end{array}$ 


\section{List of Figures and Tables}

Figures

4.1 Birth and death rates, 1855-1975 71

11.1 Lorenz curve for UK and West Germany, 1964

\section{Tables}

4.1 Postwar economic cycles, 1951-73

4.2 Major stimuli to economic expansion and contraction, 1947-74

4.3 Demographic change, 1911-71

4.4 Election results, 1945-74

6.1 Social security: government expenditure, 1951-77 124

6.2 Estimates of poverty in the UK, 1950-75 140

6.3 Claimants receiving national assistance/supplementary benefit, 1948-74

6.4 Benefits as a percentage of average male manual earnings, 1948-74

6.5 The real value of social security benefits, 1948-75 153

6.6 The immediate causes of poverty, 1936-60 154

7.1 The National Health Service: selected current and capital expenditure, 1951-76

7.2 Parliamentary estimates for the NHS, 1948-52 176

7.3 NHS sources of finance, 1950/1-1974/5

8.1 Education: selected current and capital expenditure, 1951-77

8.2 Maintained nursery and primary schools, 1946-75 205

8.3 Maintained secondary schools, 1946-75 209

8.4 Students in further and higher education, 1951-75 226

9.1 Housing: selected current and capital expenditure, 1951-76

9.2 Housing constructed and demolished in the UK, 1938-76 246

9.3 Households and dwellings in England and Wales, 1951-76

9.4 Housing tenure in Britain, 1945-76

9.5 Cost of building subsidies in the UK, 1952-77

11.1 Distribution of personal income in Britain, 1949-75/6 283 
11.2 Distribution of personal wealth in England and Wales 1950-76

12.1 Public expenditure, 1974/5-1989/90

12.2 Social expenditure, 1975/6-1987/8

A.1 Government expenditure, central and local, 1945-75

A.2 Public expenditure by economic category, 1955-76

A.3 Public expenditure, 1951-75, selected services

A.4 Social expenditure, 1951-77

A.5 Social expenditure, annual growth relative to growth of GDP, 1950-77 


\section{Acknowledgements}

My foremost debt is to all those who have written on the welfare state and whose work I have used. My foremost obligation, therefore, is to apologise to those whose views I have failed to acknowledge, have caricatured or, worse still, have ignored. I should also apologise to readers in Scotland and Northern Ireland who will immediately perceive, with resignation, that this is yet another book which focuses essentially on England and Wales. The reasons for this are twofold. I simply do not as yet have the necessary expertise to write on welfare policy in their countries; and the inclusion of such information would have made even more complex a book which many may feel is too long already. It is an omission which I hope to remedy in a second edition, should one be commissioned.

I should like to thank the University of Bristol, the Nuffield Foundation and the Economic and Social Research Council for their financial support over the past five years. The grant from the ESRC enabled me jointly to edit' The Development of the Welfare State, 1939-51: a guide to documents in the Public Record Office (HMSO, 1992) which, it is hoped, will stimulate and facilitate research in this area. I should also like to thank my editor, Vanessa Graham, for her patience; Anne Griffiths, Penny Grigg, Jean Richards and Anita Hathway for wrestling with the manuscript; my wife, Sue, for her readiness to correct everything I have written (or indeed said); and Gini, Alex and the cat for coping, in their own peculiar ways, with my preoccupations.

RoDNey Lowe 